\title{
ANALISIS FAKTOR RISIKO KEJADIAN PREEKLAMPSIA BERAT \\ DI RSUD RUJUKAN KABUPATEN DAN PROVINSI KALIMANTAN TENGAH
}

\author{
Legawati ${ }^{1}$ Nang Randu Utama ${ }^{2}$ \\ Program Studi Diploma III Kebidanan dan Diploma III Keperawatan Poltekkes Kemenkes \\ Palangka Raya Jl. George Obos No.30 Palangka Raya Provinsi Kalimantan Tengah,Indonesia \\ Korespondensi Penulis:legawati_poltekkes81@yahoo.com
}

\begin{abstract}
ABSTRAK
Angka kematian ibu (AKI) dan angka kematian bayi (AKB) merupakan barometer pelayanan kesehatan suatu Negara. Berdasarkan pengamatan World Health Organization (WHO), AKI diperkirakan sebesar 359 kematian maternal per 100.000 kelahiran hidup. Gambaran AKI menunjukkkan trend yang meningkat dari tahun 2007 sejumlah 228 per 100.000 kelahiran hidup (BPS Macro, 2012). Menurut World Health Organization (WHO), salah satu penyebab morbiditas dan mortalitas ibu dan janin adalah pre-eklamsia berat (PEB), angka kejadiannya berkisar antara 0,51\%-38,4\%. Di negara maju angka kejadian preeklampsia berat berkisar 6-7\% dan eklampsia 0,1-0,7\%. Sedangkan angka kematian ibu yang diakibatkan pre-eklampsia berat dan eklampsia di negara berkembang masih tinggi (Betty \& Yanti, 2011) Untuk menganalisis faktor risiko kejadian Pre eklampsia Berat di RSUD Rujukan Sultan Imanudin Pangkalan Bun dan dr Doris Sylvanus Palangka Raya. Manfaat praktis penelitian ini dapat membantu kebijakan tentang analisis faktor risiko kejadian Pre Eklampsia Berat sehingga memudahkan dalam penanganan dan penatalaksanaan sebagai langkah pencegahan terjadinya Eklampsia. Jenis penelitian yang dilaksanakan adalah observasional menggunakan rancangan Cross Sectional Study. Rancangan cross sectional study adalah bila pengaruh antara variabel bebas (paparan) dan variabel terikat (efek) diamati dan diukur pada waktu yang bersamaan. Berdasarkan hasil analisis multivariabel dengan regresi logistik faktor yang mempengaruhi faktor risiko PEB adalah umur ibu, pendidikan, umur kehamilan, paritas, ANC. Faktor yang tidak berhubungan secara signifikan adalah pekerjaan, spasing, riwayat $\mathrm{PE}$, riwayat DM, gemelli, social ekonomi dan pengambilan keputusan. Faktor yang meningkatkan risiko PEB adalah umur ibu, pendidikan, pekerjaan, umur kehamilan, paritas, riwayat PE, ANC dan social ekonomi . Faktor yang tidak berhubungan secara signifikan adalah spasing, riwayat DM, gemelli, dan pengambilan keputusan. Untuk ibu hamil dapat melakukan pemeriksaan kehamilan tanpa melihat faktor risiko kejadian PEB maupun tanpa faktor risiko, dengan melihat beberapa faktor risiko penentu.Untuk tenaga kesehatan agar dapat melaksanakan pemeriksaan kehamilan dengan fokus pada kehamilan tersebut.
\end{abstract}

Keyword : Faktor Risiko, Pre Eklampsia Berat, Outcome maternal and perinatal 


\section{ABSTRACS}

The maternal mortality rate (MMR) and infant mortality rate (IMR) is a barometer of a country's health services. Based on the observations World Health Organization (WHO), the MMR was estimated at 359 maternal deaths per 100,000 live births. AKI picture, indicating an increasing trend from 2007 a number of 228 per 100,000 live births (BPS Macro, 2012). According to the World Health Organization (WHO), one of the causes of morbidity and mortality of mother and fetus are severe pre-eclampsia (PEB), incidence rates ranged between $0.51 \%-38.4 \%$. In developed countries the incidence of severe preeclampsia and eclampsia ranges from 6-7\% 0.1 to $0.7 \%$. While the maternal mortality rate due to pre-eclampsia and eclampsia in developing countries is still high (Betty \& Yanti, 2011). To analyze the risk factors of weight in Pre eclampsia Referral Hospital Sultan Imanudin Pangkalan Bun and Dr. Doris Sylvanus Palangkaraya. Benefits Research: Practical benefits of this research can help policy analysis of risk factors, the incidence of Pre Eclampsia so as to facilitate the handling and management as a precautionary measure the occurrence of Eclampsia. This was an observational study conducted using a cross sectional study design. Cross sectional study is when the influence of independent variables (exposure) and the dependent variable (effect) is observed and measured at the same time. Based on multivariable logistic regression analysis of factors affecting the risk factors PEB is the mother's age, education, gestational age, parity, ANC. Factors unrelated significantly is work, spasing, PE history, history of diabetes, Gemelli, economic and social decision-making. Factors that increase the risk of PEB is the mother's age, education, occupation, gestational age, parity, history of PE, the ANC and the social economy. Factors unrelated significantly is spasing, history of diabetes, Gemelli, and decision making. For pregnant women can do a pregnancy without looking at risk factors of PEB or no risk factors, to see some of the risk factors determinants. For health workers to carry out pregnancy tests with a focus on the pregnancy.

Keyword: Risk Factors, Pre Eclampsia, maternal and perinatal outcome 


\section{PENDAHULUAN}

Angka kematian ibu (AKI) dan angka kematian bayi (AKB) merupakan barometer pelayanan kesehatan suatu Negara. Berdasarkan pengamatan World Health Organization (WHO), AKI diperkirakan sebesar 359 kematian maternal per 100.000 kelahiran hidup. Gambaran AKI menunjukkkan trend yang meningkat dari tahun 2007 sejumlah 228 per 100.000 kelahiran hidup (BPS Macro, 2012)

Berdasarkan survey demografi kesehatan Indonesia (SDKI) tahun 2012 di Indonesia AKI mencapai 359 per 100.000 kelahiran hidup dan AKB mencapai 34 per 1.000 kelahiran hidup. angka ini masih jauh dari target yang harus dicapai dalam millennium development goals (MDG's) 2015 yaitu untuk AKI sebesar 102 per 100.000 kelahiran hidup dan untuk AKB sebesar 17 per 1.000 kelahiran hidup (BPS Macro, 2012)

Berdasarkan data badan pusat statistic (BPS) Provinsi kalteng tahun 2013, AKI di Provinsi Kalimantan Tengah sebesar 359 per 100.000 kelahiran hidup dan menduduki peringkat tertinggi dari seluruh regional kalimantan Jumlah Kematian Ibu yang dilaporkan di Provinsi Kalimantan Tengah pada Tahun 2014 sebesar 101 kasus, lebih besar bila dibandingkan dengan tahun 2013 sebesar 75 kasus. Trend kasus kematian ibu dari tahun ke tahun terus mengalami peningkatan ini menjadi tantangan bagi seluruh stakeholder yang berkecimpung di bidang kesehatan (Dinkes Prov Kalteng, 2014).

Menurut World Health Organization (WHO), salah satu penyebab morbiditas dan mortalitas ibu dan janin adalah pre-eklamsia berat (PEB), angka kejadiannya berkisar antara 0,51\%-38,4\%. Di negara maju angka kejadian preeklampsia berat berkisar 6-7\% dan eklampsia 0,1-0,7\%. Sedangkan angka kematian ibu yang diakibatkan preeklampsia berat dan eklampsia di negara berkembang masih tinggi (Betty \& Yanti, 2011)

Di Indonesia, preeklamsia berat dan eklamsia merupakan penyebab dari 30\%$40 \%$ kematian maternal, sementara di beberapa rumah sakit di Indonesia telah menggeser perdarahan sebagai penyebab utama kematian maternal. Oleh karena itu di perlukan perhatian, serta penanganan yang serius terhadap ibu bersalin dengan penyakit komplikasi ini (Yuliati dan Fikawati, 2012).

\section{Preeklampsia berat daneklampsia} merupakan risiko yang membahayakan ibu di samping membahayakan janin melalui placenta. Beberapa kasus memperlihatkan keadaan yang tetap ringan sepanjang kehamilan. jika preeklamsia berat tidak ditangani dengan baik maka pasien akan mengalami kejang dan berlanjut ke eklamsia. Demikian pula Jika eklampsia tidak ditangani secara cepat akan terjadi kehilangan kesadaran dan kematian karena kegagalan 
Legawati dan Nang Randu Utama

jantung, kegagalan ginjal, kegagalan hati atau perdarahan otak. Oleh karena itu

Jurnal Surya Medika Volume 3 No. 1 [2017] 
Analisis Faktor Risiko Kejadian Preeklampsia Berat Di Rsud Rujukan Kabupaten Dan Provinsi Kalimantan Tengah

kejadian kejang pada penderita preeklamsia berat dan eklampsia harus dihindari. Karena eklampsia menyebabkan angka kematian sebesar 5\% atau lebih tinggi (Omilabu et all, 2014).

Beberapa penelitian menyebutkan ada beberapa faktor penunjang terjadinya preeklamsia berat yaitu kehamilan yang pertama, kehamilan di usia remaja, dan kahamilan pada wanita di atas usia 40 tahun (Rukiyah, 2010).Penelitian lain menemukan bahwa ada faktor karakteristik maternal dan riwayat medis yang menjadi faktor risiko kejadian pre eklampsia (Wright et all, 2015)

Demikian pula hasil penelitian yang dilakukan oleh English et all (2015) menemukan bahwa multi faktor yang menjadi faktor risiko kejadian pre eklampsia seperti riwayat keluarga, nullipara, sel telur donor, diabetes dan obesitas. Hasil penelitian lain juga mengatakan bahwa ibu hamil yang diberi suplemen kalsium cukup, kasus yang mengalami preeklamsia berat adalah $14 \%$, sedangkan yang diberi glukosa adalah $17 \%$ (Sarwono, 2010).

Rumah Sakit merupakan sarana kesehatan Strata dua dan strata 3. Indikator yang digunakan untuk menilai perkembangan sarana Rumah Sakit (RS) antara lain dengan melihat perkembangan fasilitas perawatan yang biasanya diukur dengan jumlah Rumah Sakit dan tempat tidurnya serta rasio terhadap jumlah penduduk. Setiap Kabupaten memiliki rumah sakit dan RSUD Sultan Imanudin Pangkalan Bun serta RSUD dr Doris Sylvanus Palangka Raya merupakan dua RSUD terbesar dengan rujukan terbanyak dari beberapa kabupaten disekitarnya (Dinkes Provinsi Kalteng, 2014).

Kematian Ibu dan Anak merupakan dua indikator yang peka terhadap kualitas fasilitas pelayanan kesehatan. Kualitas fasilitas pelayanan kesehatan yang dimaksud termasuk aksesibilitas terhadap fasilitas pelayanan kesehatan itu sendiri. Keadaan kesehatan sangat penting dalam menggambarkan profil kesehatan masyarakat di suatu daerah. Dalam menilai derajat kesehatan masyarakat, digunakan indikator Angka Kematian Bayi (AKB) dan Angka Kematian Ibu (AKI). Faktor-faktor yang memengaruhi derajat kesehatan masyarakat tidak hanya berasal dari sektor kesehatan melainkan juga dipengaruhi oleh faktor ekonomi, pendidikan, lingkungan sosial, keturunan, dan faktor lainnya (Dinkes Provinsi Kalteng, 2014).

Angka kejadian Pre eklampsia yang merupakan penyebab kedua kasus kesakitan dan kematian yang terjadi di Provinsi Kalimantan Tengah yang memberikan sumbangan tinggi untuk kasus rujukan di RSUD Rujukan Komprehensif sehingga perlu dilakukan sebuah analisis dan intervensi dari tenaga kesehatan, pengambil kebijakan yang 
bersifat lintas program dan lintas sektoral dalam penanganan kejadian tersebut, sehingga mampu dilakukan deteksi dan tata laksanan se dini mungkin (Dinkes Provinsi Kalteng, 2014)

\section{METODOLOGI PENELITIAN}

Jenis penelitian ini adalah penelitian deskriptif observasional, dengan rancangan cohortProspective Study $\mathrm{Hal}$ ini dilakukan untuk melihat gambaran suatu populasi pada dilakukan deteksi secara dini faktor predisposisi pada ibu hamil setelah diberikan perlakuan ANC terintegrasi. Pada penelitian

\section{Hasil}

\section{Analisis Univariabel}

Tabel 4.1 Distribusi frekuensi subjek penelitian menurut karakteristik

\begin{tabular}{|c|c|c|c|c|c|c|c|}
\hline \multirow{2}{*}{\multicolumn{2}{|c|}{ Karakteristik }} & \multicolumn{4}{|c|}{ Pre Eklampsia } & \multirow{2}{*}{\multicolumn{2}{|c|}{ Total }} \\
\hline & & \multicolumn{2}{|c|}{$\mathrm{Ya}$} & \multicolumn{2}{|c|}{ Tidak } & & \\
\hline & & $\mathrm{N}$ & $\%$ & $\mathrm{~N}$ & $\%$ & $\mathrm{~N}$ & $\%$ \\
\hline \multirow[t]{5}{*}{ Umur } & $20-35$ & 3 & 36 & 1 & 14 & 5 & 50 \\
\hline & thn & 9 & .8 & 5 & .2 & 4 & .9 \\
\hline & $<20$ thn & 1 & 13 & 3 & 35 & 5 & 49 \\
\hline & dan & 4 & .2 & 8 & .8 & 2 & .1 \\
\hline & $>35$ & & & & & & \\
\hline Pendidik & Menen & 1 & 17 & 3 & 31 & 5 & 48 \\
\hline \multirow[t]{3}{*}{ an } & gah & 8 & .0 & 3 & .1 & 1 & .1 \\
\hline & Renda & 3 & 33 & 2 & 18 & 5 & 51 \\
\hline & $\mathrm{h}$ & 5 & .0 & 0 & .9 & 5 & .9 \\
\hline Riwayat & $\mathrm{Ya}$ & 3 & 29 & 3 & 31 & 6 & 60 \\
\hline \multirow[t]{2}{*}{ DM } & Tidak & 1 & .2 & 3 & .1 & 4 & .4 \\
\hline & & 2 & 20 & 2 & 18 & 4 & 39 \\
\hline
\end{tabular}

ini pengukuran dilakukan dalam waktu bersamaan antara Faktor Maternal dan ANC terintegrasi (variabel bebas) sedangkan kejadian Prematuritas (variabel terikat) diikuti ketika ibu melahirkan.

Populasi penelitian ibu hamil di puskesmas Pahandut dan Kalampangan yang ada di wilayah kota Palangka Raya, menjadi subyek penelitian adalah ibu hamil trimester III. Dengan sampel 106 orang ibu hamil. Cara pengambilansampel pada penelitian ini dilakukan dengan cara purposive sampling.

$\begin{array}{llcccccc}\text { Pekerj } & \text { Beker } & 3 & 33 & 2 & 1 . & 3 & 34 \\ \text { aan } & \text { ja } & 5 & .0 & 5 & 9 & 7 & .9 \\ & \text { Tidak } & 1 & 17 & 1 & 48 & 6 & 65 \\ & \text { bekerj } & 8 & .0 & & .1 & 9 & .1 \\ & \text { a } & & & & & & \\ \text { Umur } & \text { Preter } & 1 & 16 & 1 & 11 & 2 & 27 \\ \text { Keha } & \text { m } & 7 & .0 & 2 & .3 & 9 & .4 \\ \text { milan } & \text { Atern } & 3 & 34 & 4 & 38 & 7 & 72 \\ & & 6 & .0 & 1 & .7 & 7 & .6 \\ \text { Paritas } & \text { Primi } & 4 & 44 & 3 & 36 & 8 & 81 \\ & \text { para } & 7 & .3 & 9 & .9 & 6 & .1 \\ & \text { Multip } & 6 & 5 . & 1 & 13 & 2 & 18 \\ & \text { ara } & & 7 & 4 & .2 & 0 & .9 \\ \text { Jarak } & 0-2 & 4 & 44 & 4 & 46 & 9 & 90 \\ & \text { thn } & 7 & .3 & 9 & .2 & 6 & .6 \\ & \geq 2 \text { thn } & 6 & 5 . & 4 & 3 . & 1 & 9 . \\ & & & 7 & & 8 & 0 & 4 \\ \text { Riway } & \text { Ya } & 3 & 32 & 1 & 17 & 5 & 49 \\ \text { at PE } & \text { Tidak } & 4 & .1 & 8 & .0 & 2 & .1\end{array}$




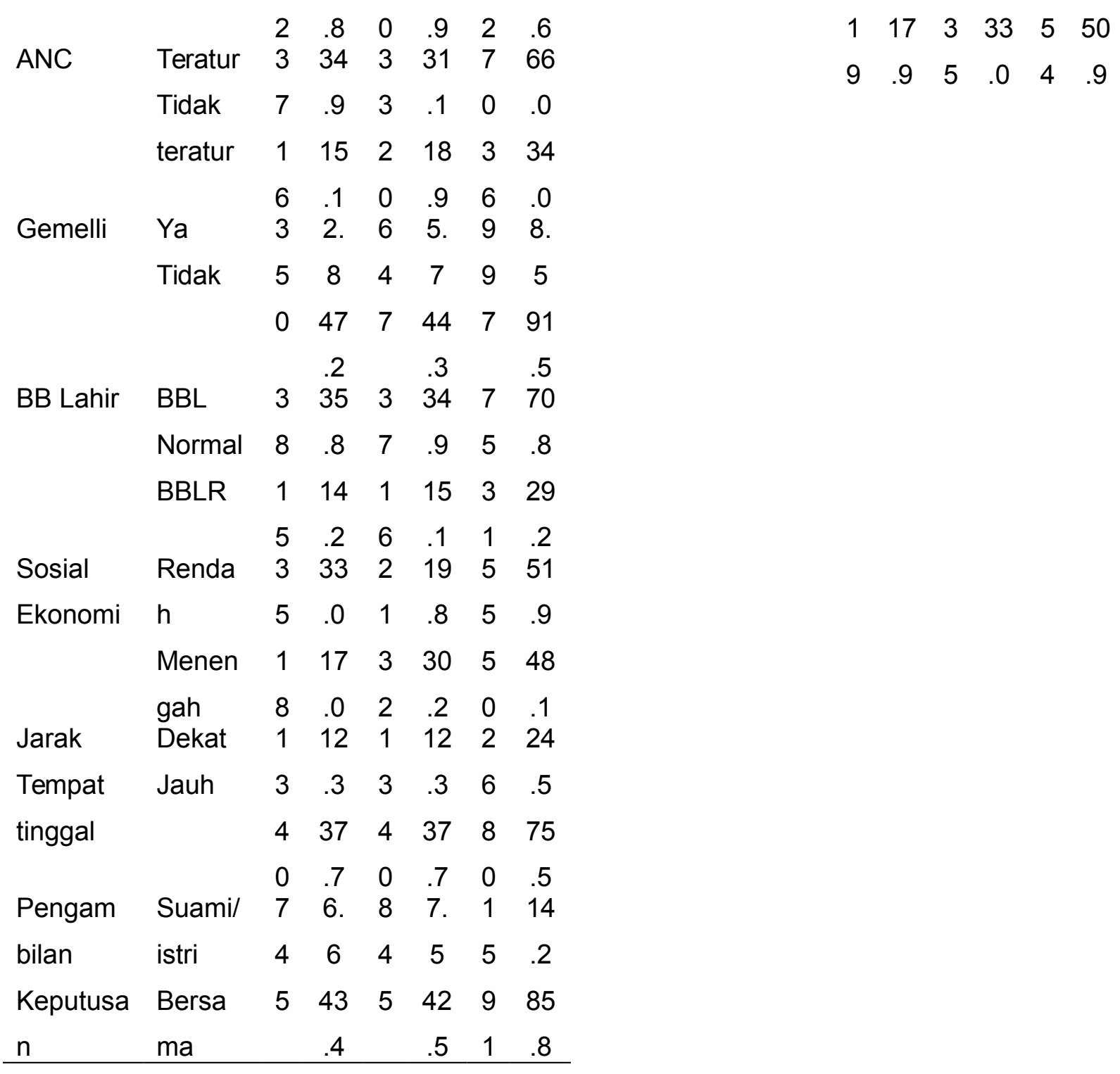




\section{Analisis Bivariabel}

Tabel 4.2 Analisis bivariabel

Variabel

$$
\mathrm{N} \underset{\%}{\mathrm{Ya}} \stackrel{\mathrm{N}}{\mathrm{N}} \% x^{2} \quad \mathrm{RR} \quad 95 \% \mathrm{Cl} \quad p
$$

Umur

$\begin{array}{llccccccc}\text { - } 20-35 \text { thn } & 3 & 36 . & 15 & 14 & 21 . & 0.1 & 0.06- & 0.0\end{array}$

$\begin{array}{llllllllll}-\quad<20 \text { th dan } & 9 & 8 & 38 & .2 & 74 & 42 & 0.33 & 00\end{array}$ $>35$ th 42 8

Pendidikan

- Menengah

$\begin{array}{cccccccc}3 & 33 . & 20 & 18 & 8.5 & 3.2 & 1.45- & 0.0\end{array}$

- Menengah

Pekerjaan

- Bekerja

- Tidak bekerja

$\begin{array}{cccc}5 & 0 & 33 & .9 \\ 1 & 27 . & & 2 . \\ 8 & 4 & & 8\end{array}$

8

Umur

Kehamilan

- Preterm

$\begin{array}{lll}3 & 33 \\ 5 & 17\end{array}$

33

2
51

1. 45. 49. $10.8-0.0$

- Aterm

Paritas

- Primipara

- Multipara

$\begin{array}{cccccccc}4 & 44 . & 39 & 36 & 3.9 & 2.8 & 0.99- & 0.0 \\ 7 & 3 & 14 & .9 & 5 & & 8.01 & 47 \\ 6 & 5.7 & & 13 & & & & \\ & & & .2 & & & & \end{array}$

Jarak

kehamilan

- 0-2 thn

- $\geq 2$ thn

$$
\begin{array}{cccccccc}
4 & 44 . & 49 & 46 & 0.4 & 0.6 & 0.17- & 0.5 \\
7 & 3 & 4 & .2 & 4 & 4 & 2.41 & 08
\end{array}
$$

Riwayat

$\begin{array}{lllllllll}\mathrm{DM} & 3 & 29 & 3 & 31 & 0.1 & 1.1 & 0.5 & 0\end{array}$

$\begin{array}{lllllllll}- & \text { Ya } & 1 & .2 & 3 & .1 & 58 & 7 & 3-\end{array}$

$\begin{array}{lcccccc}\text { - } \text { Tidak } & 2 & 20 & 2 & 18 & 2.5 & 6 \\ & 2 & .8 & 0 & .9 & 5 & 9\end{array}$

ANC

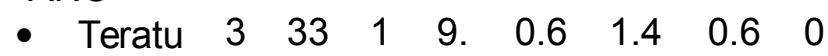

$\begin{array}{llllllll}r & 5 & 17 & 0 & 4 & 73 & 02 & 2-\end{array}$.

- Tidak $1 \quad 4040 \quad 3.14$ $\begin{array}{llllll}\text { teratu } & 8 & 3 & .6 & 43 & 1 \\ & & & & 4\end{array}$

$r$

Gemelli

$\begin{array}{lllllllll}\text { - } Y a & 3 & 2 . & 6 & 5 . & 1.0 & 2.1 & 0.5 & 0\end{array}$

$\begin{array}{lccccccccc}\text { - } \text { Tidak } & 5 & 8 & 4 & 7 & 9 & 3 & 03- & \text {. } \\ & 0 & 47 & 7 & 44 & & & 8.9 & 2\end{array}$

$\begin{array}{lllllllll}\text { Ekonomi } & 3 & 33 & 2 & 18 & 7.4 & 2.9 & 1.3 & 0\end{array}$

$\begin{array}{llllllllll}\text { - Rend } & 5 & .0 & 0 & .9 & 2 & 6 & 4- & \text {. } \\ & 1 & 17 & 3 & 30 & & & 6.5 & 0\end{array}$ $\begin{array}{llllllll}\text { ah } & 1 & 17 & 3 & 30 & 6.5 & 0\end{array}$

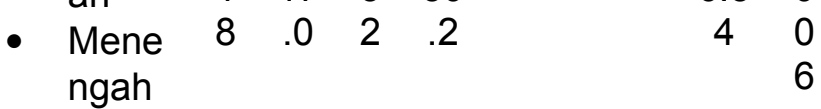

Keterangan:

$\begin{array}{ll}\mathrm{x}^{2} & : \text { Chi Square } \\ \mathrm{p} & : p \text { value (signifikan) } \\ \mathrm{RR} & : \text { Risk Rasio } \\ 95 \% \mathrm{Cl} & \quad: 95 \% \text { Confidence Interval }\end{array}$


Legawati dan Nang Randu Utama

Riwayat PE

- Ya

$\begin{array}{cccccccc}3 & 32 . & 18 & 17 & 9.6 & 0.2 & 0.129- & 0.0 \\ 4 & 1 & 35 & 33 & 6 & 8 & 0.639 & 02 \\ 1 & 17 . & & & & & & \\ 9 & 9 & & & & & & \end{array}$


Pada Tabel 4.2 terlihat bahwa faktor yang Sebagai tindaklanjut dari analisis bivariabel berhubungan dengan kejadian Pte Eklampsia maka dilakukan analisis multivariabel. Analisis Berat adalah umur ibu, pendidikan ibu, multivariabel dilakukan dengan menggunakan pekerjaan ibu, paritas, riwayat Pre eklampsia permodelan yang bertujuan untuk melihat dan sosial ekonomi. Faktor yang tidak hubungan antara variabel bebas dan variabel berhubungan dengan PEB adalah umur terikat dengan melibatkan semua variabel kehamilan, jarak antara kehamilan, riwayat bebas tanpa melihat hubungan kebermaknaan DM, frekuensi ANC dan gemell Analisis dalam analisis bivariabel.

\section{Multivariabel}

Tabel 4.3 Analisa Logistic Regression: Kejadian Pre Eklampsia Berat dan faktor yang mempengaruhinya secara significant

\begin{tabular}{lccc}
\hline \multicolumn{1}{c}{ Variabel } & SE & $\begin{array}{c}\text { Signifikant ( P } \\
\text { Value) }\end{array}$ & $95 \% \mathrm{Cl}$ \\
\hline Umur Ibu & 1.858 & 0.007 & $3.994-5.824$ \\
Pendidikan & 2.486 & 0.019 & $0.000-0.376$ \\
Pekerjaan & 6.053 & 0.994 & 0.000 \\
Umur Kehamilan & 2.362 & 0.010 & $0.000-0.242$ \\
Paritas & 3.238 & 0.013 & $5.626-1.834$ \\
Spasing & 2.385 & 0.184 & $0.000-4.514$ \\
Riwayat PE & 1.138 & 0.161 & $0.513-45.89$ \\
Riwayat DM & 1.396 & 0.071 & $0.804-191$ \\
ANC & 1.828 & 0.004 & $5.56-7.202$ \\
Gemelli & 4.541 & 0.113 & $0.000-5.484$ \\
Sosial ekonomi & 6.5053 & 8.17 & 0.000 \\
Pengambilan & 2.390 & 0.938 & $0.008-89.992$ \\
Keputusan & & & \\
\hline
\end{tabular}

Berdasarkan hasil analisis multivariabel dengan regresi logistik faktor yang mempengaruhi faktor risiko PEB adalah umur ibu, pendidikan, umur kehamilan, paritas, pengambilan keputusan.
ANC. Faktor yang tidak berhubungan secara signifikan adalah pekerjaan, spasing, riwayat $P E$, riwayat $D M$, gemelli, social ekonomi dan 
meningkatkan kejadian PEB dimana

\section{Pembahasan}

Penelitian yang dilakukan menemukan bahwa terdapat hubungan yang bermakna antara umur ibu dengan kejadian PEB, berdasarkan hasil analisis bivariabel dan multivariable. Penelitian Karima, dkk (2015) terdapat hubungan yang bermakna antara umur ibu dengan kejadian Pre Eklampsia Berat. Dimana kejadian Pre Eklampsia meningkat pada ibu yang berumur $>35$ thn. Penelitian Shamsi et al (2013) menemukan tingginya proporsi kasus PEB pada umur yang ekstrim untuk usia reproduksi, dimana wanita yang berusia diatas 40 tahun memiliki 2 kali faktor risiko PEB tanpa memperhatikan apakah primipara atau multipara.

Penelitian Omilabu et al (2014) juga menemukan kejadian PEB banyak terjadi pada multipara dengan umur $>40$ tahun di Lagos Nigeria. Menurut Wright et al (2015) faktor risiko yang meningkatkan kejadian PEB adalah umur maternal diatas 35 tahun. Penelitian lain yang dilakukan oleh North et al (2011) juga menemukan terdapat hubungan yang signifikan antara Umur dengan kejadian PEB terutama pada nullipara. Menurut Sutarna and Aparna (2013) kejadian PEB meningkat pada ibu yang hamil pada usia remaja. Penelitian lain yang mendukung adalah Moselhy etal (2011) menyatakan bahwa umur yang semakin muda pada saat hamil pertama kali akan penelitian ini membandingkan kejadian PEB pada 3 kelompok umur. Semakin muda umur ibu makan akan semakin meningkatkan peluang mengalami PEB. Menurut Bilano et al (2014) menyatakan bahwa umur meningkatkan kejadian PEB, pada umur $>30$ tahun.

Penelitian yang dilakukan menemukan bahwa terdapat hubungan yang bermakna antara pendidikan ibu dengan kejadian PEB, berdasarkan hasil analisis bivariabel dan multivariable. Penelitian yang dilakukan oleh North et al (2011) menyatakan bahwa tidak terdapat hubungan yang signifikan antara pendidikan dengan kejadian PEB dimana tidak terdapat perbedaan kejadian PEB pada kelompok ibu pendidikan tinggi dan rendah. Penelitian lain yang berbeda adalah Moselhy et al (2011) menyatakan bahwa ibu dengan pendidikan rendah meningkatkan peluang kejadian PEB dengan membandingkan kelompok ibu hamil berdasarkan pendidikannya.

Penelitian yang lainnya dilakukan oleh Moghadam et al (2012) menemukan bahwa terdapat hubungan yang bermakna dalam meningkatkan faktor risiko kejadian PEB dengan pendidikan ibu $\mathrm{p}$ value 0.04 . Menurut Bilano et al (2014) menyatakan bahwa pendidikan meningkatkan kejadian PEB, pada ibu yang tidak memiliki pendidikan memiliki peluang meningkatkan risiko kejadian PEB. 
Penelitian yang dilakukan menemukan bahwa terdapat hubungan yang bermakna antara umur ibu dengan kejadian PEB, berdasarkan hasil analisis bivariabel, akan tetapi setelah dilakukan analisis multivariable ditemukan hubungan yang tidak bermakna.. Penelitian yang dilakukan oleh North et al (2011) menemukan tidak terdapat hubungan yang signifikan atau perbedaan kejadian PEB pada kelompok ibu yang bekerja parttime maupun fulltime. Jadi Pekerjaan bukan merupakan faktor predisposisi meningkatnya kejadian PEB. Penelitian lain yang berbeda adalah Moselhy et al (2011) menyatakan bahwa pekerjaan sebagai ibu rumah tangga meningkatkan kejadian PEB 1,44 kali dibandingkan professional. Penelitian yang lainnya dilakukan oleh Moghadam et al (2012) menemukan bahwa tidak terdapat hubungan yang bermakna dalam meningkatkan faktor risiko kejadian PEB dengan pekerjaan ibu ( membandingkan ibu bekerja dan tidak bekerja) dengan angka $\mathrm{p}$ value 0.09 .

Penelitian yang dilakukan menemukan bahwa tidak terdapat hubungan yang bermakna antara umur kehamilan dengan kejadian PEB, berdasarkan hasil analisis bivariabel, akan tetapi setelah dilakukan analisis multivariable ditemukan bahwa umur kehamilan memiliki hubungan yang bermakna dengan kejadian PEB. Menurut Penelitian Karima, dkk (2015) tidak terdapat hubungan yang bermakna antara umur ibu dengan kejadian Pre Eklampsia Berat. Kejadian PEB dapat terjadi pada semua kategori usia kehamilan diatas 20 minggu. Menurut Wright et al (2015) tidak terdapat hubungan antara usia kehamilan dengan kejadian Pre Eklampsia. Penelitian lain yang dilakukan oleh North et al (2011) juga menemukan terdapat hubungan yang signifikan antara Umur kehamilan dengan kejadian PEB dengan membandingkan dua kelompok ibu hamil berdasarkan usia kehamilannya. Penelitian lain yang mendukung adalah Moselhy et al (2011) menyatakan bahwa prematuritas dapat meningkatkan kejadian $\mathrm{PEB}$ dengan angka $\mathrm{P}$ value 0.04. Penelitian lain menurut Karima, dkk (2015) menyatakan bahwa umur kehamilan tidak memiliki hubungan yang signifikan dengan kejadian PEB.

Penelitian yang dilakukan menemukan bahwa terdapat hubungan yang bermakna antara paritas dengan kejadian PEB, berdasarkan hasil analisis bivariabel dan multivariable. Menurut Penelitian Karima, dkk (2015) tidak terdapat hubungan yang bermakna antara paritas ibu dengan kejadian Pre Eklampsia Berat. Kejadian PEB dapat terjadi pada primigravida dan multi gravida. Penelitian Langelo et al (2012) juga membuktikan bahwa tidak terdapat hubungan antara jumlah paritas dengan kejadian PEB. Penelitian Omilabu et al (2014) juga menemukan kejadian PEB banyak terjadi pada multipara di Lagos 
Nigeria. Menurut Wright et al (2015) PEB banyak dialami oleh Nullipara (melahirkan pertama kali) dibandingkan dengan Multipara.

Penelitian lain yang dilakukan oleh North et al (2011) juga menemukan terdapat hubungan yang signifikan antara paritas dengan kejadian PEB terutama pada nullipara yang dilakukan prediksi $21 \%$ mengalami PEB. Menurut Sutarna and Aparna (2013) kejadian PEB meningkat pada kehamilan primipara. Penelitian lain yang mendukung adalah Moselhy et al (2011) menyatakan bahwa primipara memiliki peluang 2,16 kali lebih besar mengalami PEB dibandingkan dengan multipara. Penelitian yang lainnya dilakukan oleh Moghadam et al (2012) menemukan bahwa terdapat hubungan yang bermakna dalam meningkatkan faktor risiko kejadian PEB dengan paritas ibu dengan angka $p$ value 0.001. Menurut Bilano et al (2014) menyatakan bahwa paritas meningkatkan kejadian PEB, dengan membandingkan antara primipara dan multipara, dimana primipara meningkatkan kejadian PEB 2.04 kali dan $\mathrm{p}$ value $<0.001$.

Penelitian yang dilakukan menemukan bahwa tidak terdapat hubungan yang bermakna antara jarak antara kehamilan (spasing) dengan kejadian PEB, berdasarkan hasil analisis bivariabel dan multivariable. Penelitian Shamsi et al (2013) menemukan bahwa pada waktu yang lama interval atau jarak antara kehamilan akan meningkatkan kejadian PEB terutama pada jarak yang terlalu pendek. Menurut Wright et al (2015) faktor risiko yang meningkatkan kejadian PEB adalah jarak antara kehamilan yang terlalu pendek. Jarak (spasing) antar kehamilan yang kurang dari 1 tahun akan meningkatkan kejadian PEB pada kehamilan selanjutnya. Penelitian lain Moselhy et al (2011) menyatakan bahwa interval atau jarak antara kehamilan $>3$ tahun akan meningkatkan kejadian PEB 2,73 kali lebih besar.

Penelitian yang dilakukan menemukan bahwa terdapat hubungan yang bermakna antara riwayat Pre Eklampsia dengan kejadian PEB, berdasarkan hasil analisis bivariabel, akan tetapi setelah dilakukan analisis multivariable ditemukan tidak terdapat hubungan yang bermakna. Menurut Penelitian Karima, dkk (2015) terdapat hubungan yang bermakna antara riwayat pre eklampsia pada kehamilan sebelumnya dengan kejadian Pre Eklampsia Berat berulang. Penelitian Aminah (2010) juga menemukan bahwa riwayat pre eklampsia meningkatkan angka kejadian PEB. Penelitian ini didukung oleh Shamsi et al (2013) menemukan ibu yang mendapatkan PEB pada kehamilan yang pertama akan memiliki faktor risiko lebih tinggi mengalami PEB pada kehamilan yang selanjutnya. Menurut Penelitian Omilabu et al (2014) juga menemukan kejadian PEB banyak terjadi 
pada multipara yang mengalami PEB pada kehamilan sebelumnya dengan riwayat Hipertensi dalam keluarga. Menurut Wright et al (2015) faktor risiko yang meningkatkan kejadian PEB adalah riwayat PEB pada kehamilan sebelumnya dan ada riwayat hipertensi dalam keluarga. Penelitian lain yang mendukung adalah Moselhy et al (2011) menyatakan bahwa riwayat Pre eklampsia akan meningkatkan kejadian PEB 2,85 kali lebih besar. Penelitian yang mendukung lainnya dilakukan oleh Moghadam et al (2012) menemukan bahwa riwayat pre eklampsia akan meningkatkan faktor risiko kejadian PEB pada kehamilan selanjutnya. Menurut Bilano et al (2014) menyatakan bahwa riwayat hipertensi dan PEB meningkatkan kejadian PEB 7.75 dan $p$ value $<0.001$. Penelitian lain menurut Karima, dkk (2015) menyatakan bahwa riwayat Pre Eklampsia memiliki hubungan yang signifikan dengan kejadian PEB.

Penelitian yang dilakukan menemukan bahwa tidak terdapat hubungan yang bermakna antara riwayat DM ibu dengan kejadian PEB, berdasarkan hasil analisis bivariabel dan multivariable. Penelitian yang dilakukan oleh Shamsi et al (2013) menemukan ibu yang mendapatkan DM pada kehamilan yang pertama akan memiliki faktor risiko lebih tinggi mengalami PEB pada kehamilan yang selanjutnya. Penelitian Omilabu et al (2014) juga menemukan kejadian PEB banyak terjadi pada wanita yang memiliki riwayat DM. Menurut Wright et al (2015) faktor risiko yang meningkatkan kejadian PEB adalah ibu yang pernah memiliki riwayat DM type 1 atau 2. Penelitian lain yang mendukung adalah Moselhy et al (2011) menyatakan bahwa ibu yang mengalami DM atau memiliki riwayat DM akan meningkatkan peluang kejadian PEB 3.35 kali lebih besar. Menurut Bilano et al (2014) menyatakan bahwa riwayat DM meningkatkan kejadian PEB 2.00 dengan $p$ value $<0.001$

Penelitian yang dilakukan menemukan bahwa tidak terdapat hubungan yang bermakna antara ANC dengan kejadian PEB, berdasarkan hasil analisis bivariabel, akan tetapi setelah dilakukan analisis secara multivariable ditemukan terdapat hubungan yang bermakna. Menurut Penelitian Karima, dkk (2015) tidak terdapat hubungan yang bermakna antara umur ibu dengan kejadian Pre Eklampsia Berat. Namun penelitian berbeda dilakukan Langelo et al (2011) membuktikan bahwa terdapat hubungan antara jumlah kunjungan ANC dengan kejadian PEB. Penelitian lain yang berbeda adalah Moselhy et al (2011) menyatakan bahwa ANC tidak memiliki hubungan yang bermakna dengan kejadian PEB dengan membandingkan keteraturan ANC dan periode atau waktu melakukan ANC. Penelitian yang lainnya dilakukan oleh Moghadam et al (2012) menemukan bahwa terdapat hubungan yang bermakna dalam 
meningkatkan faktor risiko kejadian PEB dengan kunjungan ANC yang lengkap dan tidak lengkap ( $p$ value 0.003). Menurut Bilano et al (2014) menyatakan bahwa kunjungan ANC meningkatkan kejadian PEB, dimana ibu hamil yang tidak pernah melakukan ANC meningkatkan PEB 1.4 kali dengan $p$ value $<0.001$.

Penelitian yang dilakukan menemukan bahwa tidak terdapat hubungan yang bermakna antara kehamilan multipel dengan kejadian PEB, berdasarkan hasil analisis bivariabel dan multivariable. Menurut Penelitian Karima, dkk (2015) tidak terdapat hubungan yang bermakna antara gemelli/ jumlah janin dengan kejadian Pre Eklampsia Berat. Teori yang berbeda disampaikan oleh Benson and Pernol (2009) yang menyatakan bahwa salah satu keadaan klinis yang mengarah pada ke kehamilan multiple yaitu PEB- Eklampsia. Beberapa respon fisiologis ibu yang normal terhadap kehamilan diperburuk oleh adanya janin ganda. Penelitian lain yang mendukung adalah Moselhy et al (2011) menyatakan bahwa multiple gestasi akan meningkatkan kejadian PEB 9.79 kali lebih besar dibandingkan dengan tunggal gestasi. Penelitian lain menurut Karima, dkk (2015) menyatakan bahwa usia ibu tidak memiliki hubungan yang signifikan dengan kejadian PEB.

Penelitian yang dilakukan menemukan bahwa terdapat hubungan yang bermakna antara social ekonomi dengan kejadian PEB, berdasarkan hasil analisis bivariabel dan multivariable. Penelitian Shamsi et al (2013) menemukan bahwa faktor ekstrim kejadian PEB pada ibu dengan status social ekonomi yang miskin. Penelitian lain yang mendukung adalah Moselhy et al (2011) menyatakan bahwa PEB meningkat pada ibu hamil dengan sosial ekonomi rendah.

Penelitian yang dilakukan menemukan bahwa tidak terdapat hubungan yang bermakna antara pengambilan keputusan dalam keluarga dengan kejadian PEB, berdasarkan hasil analisis bivariabel dan multivariable.

\section{KESIMPULAN}

Terdapat hubungan yang bermakna antara umur ibu, pendidikan, umur kehamilan, riwayat $\mathrm{PEB}$, sosial ekonomi dan frekuensi ANC dengan kejadian PEB. Faktor yang tidak berhubungan dengan kejadian PEB adalah pendidikan, pekerjaan, paritas, spasing (jarak antara kehamilan), riwayat DM, gemelli dan pengambilan keputusan.

\section{Saran}

Untuk ibu hamil dapat melakukan pemeriksaan kehamilan tanpa melihat faktor risiko kejadian PEB maupun tanpa faktor 
risiko, dengan melihat beberapa faktor risiko penentu. Dan untuk tenaga kesehatan agar dapat melaksanakan pemeriksaan kehamilan dengan fokus pada kehamilan tersebut.

\section{DAFTAR PUSTAKA}

Badan Pusat Statistik, BKKBN, Depkes \& ORC Macro (2012), Survey demografi dan kesehatan Indonesia (SDKI). Jakarta.

Betty R.F dan Yanti.,(2011) Hubungan Karakteristik Ibu dengan Kejadian Pre Eklamsia di RSUI YAKSSI Sragen, Jurnal Kebidanan Vol III no 1

Bilano, VR., Ota,E., Ganchimeg,T., Mori,R and Souza, JP (2014) Risk Factors of Pre-Eclampsia/Eclampsia and Its Adverse Outcomes in Low and Middle Income Countries: A WHO Secondary Analysis. PLOS ONE, Vol 9, Issue, 91198

Bobak, I.M., Lowdermilk, D.L., Jensen M.D., (2005) Buku Ajar Keperawatan Maternitas edisi 4, EGC, Jakarta.

Cuningham,F.G (2002) Obstetri Williams, edisi 18, 177, EGC, Jakarta.

Cunningham, F.G., Gant, N.F., Levena, K.J., Gilstrap III, L.C., Hauth, J.C., Wenstrom, K.D ( 2006) Obstetri Williams, edisi 21, EGC, Jakarta.

El-Moselhy, E., Khaliga,H.O., Amer,SM., Mohammad,KI and Abd El-Aal,HM (2011) Risk factors and Impacts of Pre eclampsia: An Epidemiological Study among Pregnant Mothers in Cairo, Egypt. Journal of American Science, Vol 7(5)

English, F.A., KennyL.C \& Carthy F.P (2015) Risk factors and effective management of pre eclampsia. Dove Medical Press, Vol 8.7-12

Jusup, S.A ( 2008) Stress Pada Wistar Rat Hamil Sebagai Model Penelitian Pre Eklampsia. Nexus Medicus, volume 18, halamn 100.

Karkata, M.K. (2006) Faktor Risiko Terjadinya Hipertensi Dalam Kehamilan, Majalah Obstetri dan Ginekologi Indonesia, edisi Januari 2006.

Manuaba, I Gede Bagus (2007) IImu Penyakit Kebidanan, Kandungan dan Pelayanan KB untuk pendidikan Bidan, EGC, Jakarta.

Moghadam, AS., Khosavri, A and Sayehmiri, K (2012) Predictive factors for pre eclampsia in pregnant women: a univariate and multivariate logistic regression analysis. Acta Biochimica Polonica, Vol 59 No4, 673-677.

Nort, RA.,Cowan,LME., Dekker,GA., Poston, L., Chan,EHY., Stewart,AW., Black MA., Taylor, RS., Walker,JJ., Baker,PN and Kenny LC (2011) Clinical risk predition for pre- eclampsia in nulliparous women:development of model in 
Analisis Faktor Risiko Kejadian Preeklampsia Berat Di Rsud Rujukan Kabupaten Dan Provinsi Kalimantan Tengah

international prospective cohort. BMJ, 1-11 pages. 
Omilabu, A.,Okunade K.S., Gbadegesin A and Akinsola, O (2014) Risk factors for eclampsia in Multiparious Women in Lagos, Nigeria. International Journal of Biomedical Research, Vol 5 (04).

Prawirohardjo, S., Winknjosastro, H., Saifuddin, A.B., Rachimhadhi, T., (2008) Ilmu Kebidanan, Yayasan Bina Pustaka Sarwono Prawirohardjo, Jakarta.

Saifuddin, A.B (2006) Kematian lbu di Indonesia Dapatkah Kita Mencapai Target MDGS 2015, Majalah Obstetri dan Ginekologi Indonesia, volume 30.

Sastroasmoro,S dan Ismael, S. (2011) Dasar-dasar Metodologi Penelitian Klinis Edisi ke-4. Jakarta: Sagung Seto. Shamsi,U., Saleem, S and Nisthter, N (2013) Epidemiology and risk factors of pre eclampsia; an overview of observational studies. Al Ameen J Med Sci, Vol 6(4):292-300.

Syukri, M., Pranawa, 2000, Gangguan (Sistim) Organ Pada Pre Eklampsia dan Eklampsia, Majalah IImu Penyakit Dalam, volume 28.

Wright, D., Syngelaki, A., Akolekar, A., Poon, LC and Nicilaides,KH (2015) Competing risks model in screening for pre eclampsia by maternal characteristics and medical history. American Journal of Obstetrics \& Gynecology, Vol 213 (62), e 1-10

Yuliati, L dan Fikawati, S.,2008 Pre Eklampsia Berat di RSUD Bayu Asih Purwakarta, Jurnal Kesehatan Masyarakat Nasional Vol 3 No 1 